\title{
The importance of episodic weather events to the ecosystem of the Bering Sea shelf
}

\author{
NICHOLAS A. BOND ${ }^{1, *}$ AND JAMES \\ E. OVERLAND ${ }^{2}$ \\ ${ }^{1}$ University of Washington/JISAO, Box 354235, Seattle, WA \\ 98195-4235, USA \\ ${ }^{2}$ NOAA/Pacific Marine Environmental Laboratory, 7600 Sand \\ Point Way NE, Seattle, WA 98115-6349, USA
}

\begin{abstract}
Climate variability on decadal time scales is generally recognized to influence high-latitude marine populations. Our recent work in studying air-sea interactions in the Bering Sea suggests that interannual to decadal climate variability is important through its modulation of the frequencies and magnitudes of weather events on intraseasonal time scales. We hypothesize that it is these weather events that directly impact the marine ecosystem of the Bering Sea shelf. The linkages between the event-scale weather and the ecosystem are illustrated with three examples: walleye pollock (Theragra chalcogramma), Tanner crabs (Chionoecetes bairdi), and coccolithophorid phytoplankton (Emiliania huxleyi). We hypothesize that the strong recruitment of walleye pollock that occurred in 1978, 1982, and 1996 can be attributed in part due to the seasonably strong storms that occurred in the early summer of those years. These storms caused greater than normal mixing of nutrients into the euphotic zone which presumably led to sustained primary productivity after the spring bloom and, possibly, enhanced prey concentrations for pollock larvae and their competitors. Recruitment of Tanner crab was particularly strong for the 1981 and 1984 year-classes. These years had periods of prominent east wind anomalies along the Alaska Peninsula during the previous winter. Such winds promote flow through Unimak Pass, and hence an enhanced flux of nutrient-rich water onto the shelf. This mechanism may have ultimately resulted in favorable feeding conditions for Tanner crab larvae. Finally, an unprecedented coccolithophorid bloom
\end{abstract}

*Correspondence. e-mail: nicholas.bond@noaa.gov

Received 25 May 2003

Revised version accepted 6 April 2004

(C) 2005 Blackwell Publishing Ltd. occurred over the Bering Sea shelf in the summer of 1997. This summer featured lighter winds and greater insolation than usual after a spring that included a very strong May storm. This combination brought about a warm, nutrient-poor upper mixed layer by mid-summer. This provided a competitive advantage for coccolithophorid phytoplankton in 1997 and to a lesser extent in 1998. Unusually high concentrations of coccolithophores persisted for the following two years although physical environmental conditions did not remain favorable. While slow variations in the overall aspects of the physical environment may be important for setting the stage, we propose that the significant multi-year adjustments in the marine ecosystem of the Bering Sea shelf are more directly caused by major air-sea interaction events on intraseasonal time scales.

Key words: air-sea interactions, Bering Sea, ecosystem, weather events

\section{INTRODUCTION}

Much of the previous work on the impacts of climate variability on marine ecosystems of the North Pacific (e.g. Hare and Mantua, 2000; Hunt et al., 2002) stress the idea of regimes. Within a regime, particular types of physical environmental conditions tend to persist on decadal time scales. This paradigm appears to explain a substantial portion of the variability in various biological populations.

Our scrutiny of the weather of the Bering Sea (Bond et al., 1994; Bond and Adams, 2002) and the Gulf of Alaska (Stabeno et al., 2004) has motivated us to pursue a different, complementary tack. We are struck by the wide range of time scales of the fluctuations in the weather, in particular the vigor of intraseasonal (weekly to monthly) to interannual variability relative to decadal fluctuations. The Bering Sea is prone to atmospheric variability on shorter time scales because it is influenced by a host of climate modes, including those concentrated in the North Pacific (notably the Pacific North American pattern or PNA; Wallace and Gutzler, 1981; the Pacific Decadal Oscillation or PDO; Mantua et al., 1997) and in the 
Arctic (the Arctic Oscillation or AO; Thompson and Wallace, 1998; Overland et al., 1999). Our objective in this study is to examine possible effects of intraseasonal to interannual weather variability on particular species of the Bering Sea shelf marine ecosystem with different life histories. We stress the importance of major intraseasonal weather events in the creation of competitive advantages that result in rapid population increases of particular species. Unlike many climate studies, our analysis includes consideration of not just winter variability, but also that of spring and summer, as these latter periods are often crucial to the marine ecosystem.

In our study, estimates of recruitment or abundance have been used to identify extraordinary year-class successes of three particular species, in three different guilds, and to examine whether these successes can be plausibly related to physical environmental factors impacting the target species. We assess physical factors in a manner similar to that of Bond and Adams (2002), using both daily data for specific periods and seasonal averages for the 40-yr historical record. The time series are used to make plausible inferences about biological responses to physical effects. This is an appropriate approach for the eastern Bering Sea, because understanding of population dynamics is limited by the lack of fundamental knowledge and sufficiently complete data sets.

The organizing hypothesis of our study is that the Bering Sea shelf ecosystem undergoes major adjustments less due to multi-year aspects of climate variability and more due to shorter fluctuations in the atmosphereocean system. Central to this hypothesis is the concept that the primary impacts of climate regime shifts accrue from changes in the frequency distribution of extreme weather events. It has also been previously noted that the Bering Sea shelf ecosystem responded rapidly to anomalous atmospheric forcing that occurred in the warm season of 1997 (Napp and Hunt, 2001). Here we show that 1997 is not unique, and that in general, the anomalous atmospheric forcing of the ecosystem is manifested by events on intraseasonal time scales.

\section{DATA SETS AND METHODS}

Analysis of air-sea interactions over the Bering Sea shelf (Fig. 1) is based on a 40-yr record of atmospheric variables from the NCEP/NCAR Reanalysis data set (Kalnay et al., 1996). This data set was produced using a state-of-the-art numerical weather prediction (NWP) model and data assimilation system incorporating available surface, upper-air and satellite-based observations. The temporal and spatial consistency in the procedure used for the Reanalysis makes it wellsuited for studying climate variability from short-term to decadal timescales. Atmospheric parameters such as winds and fluxes are available four times daily; the sea surface temperature (SST) is resolved at monthly (pre1982) to weekly (post-1982) time scales. There are two classes of output fields: (1) prognostic variables which are closely constrained by observations, e.g. wind and pressure, and (2) diagnostic variables, which are not directly observed but derived from the general circulation model used in the data assimilation, e.g. radiative heat fluxes. The diagnostic variables are prone to greater errors, but various studies (e.g. Yang et al., 1999; Adams et al., 2000) indicate that a large fraction of these errors are due to systematic biases. These types of biases tend to be removed in calculations of anomalies, i.e. only non-linear aspects of systematic errors will be retained, and hence have minimal impacts on evaluations of anomalies.

The quality of the Reanalysis data in the Bering Sea has been directly evaluated using measurements collected by moored buoys on the Bering Sea shelf (Ladd and Bond, 2002). These measurements were not assimilated in Reanalysis, and hence represent an independent data set for validation. The synthetic winds from the Reanalysis appear to accurately characterize the actual winds, both in terms of speed and direction. Complex correlation coefficients between the measured and synthetic winds were typically about 0.9 , and systematic biases in speed $(\sim 5 \%)$ and direction $\left(\sim 10^{\circ}\right)$ were minimal. The quality of the winds from the Reanalysis was not as high for a buoy moored near the western end of the Alaska Peninsula, apparently due to the coarse resolution of the Reanalysis and hence its inability to fully account for the effects of the mountains of the Alaska Peninsula. The present analysis also considers the variability in the heating due to downward shortwave radiation (insolation) over the Bering Sea shelf, and in this respect the Reanalysis includes significant error. Specifically, the Reanalysis overestimates the insolation by 70 $80 \mathrm{~W} \mathrm{~m}^{-2}$ during the summer over the shelf. Ladd and Bond (2002) suggest that this error is due in large part to improper account of low stratus clouds and sea fog in relatively calm, fair-weather situations. At any rate, this error appears to be more-or-less systematic, and should not greatly impact estimations of year-to-year differences in solar heating of the water column.

Our analysis uses published results on variability of marine species of the Bering Sea shelf. We explore linkages between the biology and the physics that have been either hypothesized previously, or are based on our own understanding of biophysical interactions 
Figure 1. Map of the south-eastern Bering Sea. Thin lines indicate bathymetric contours.

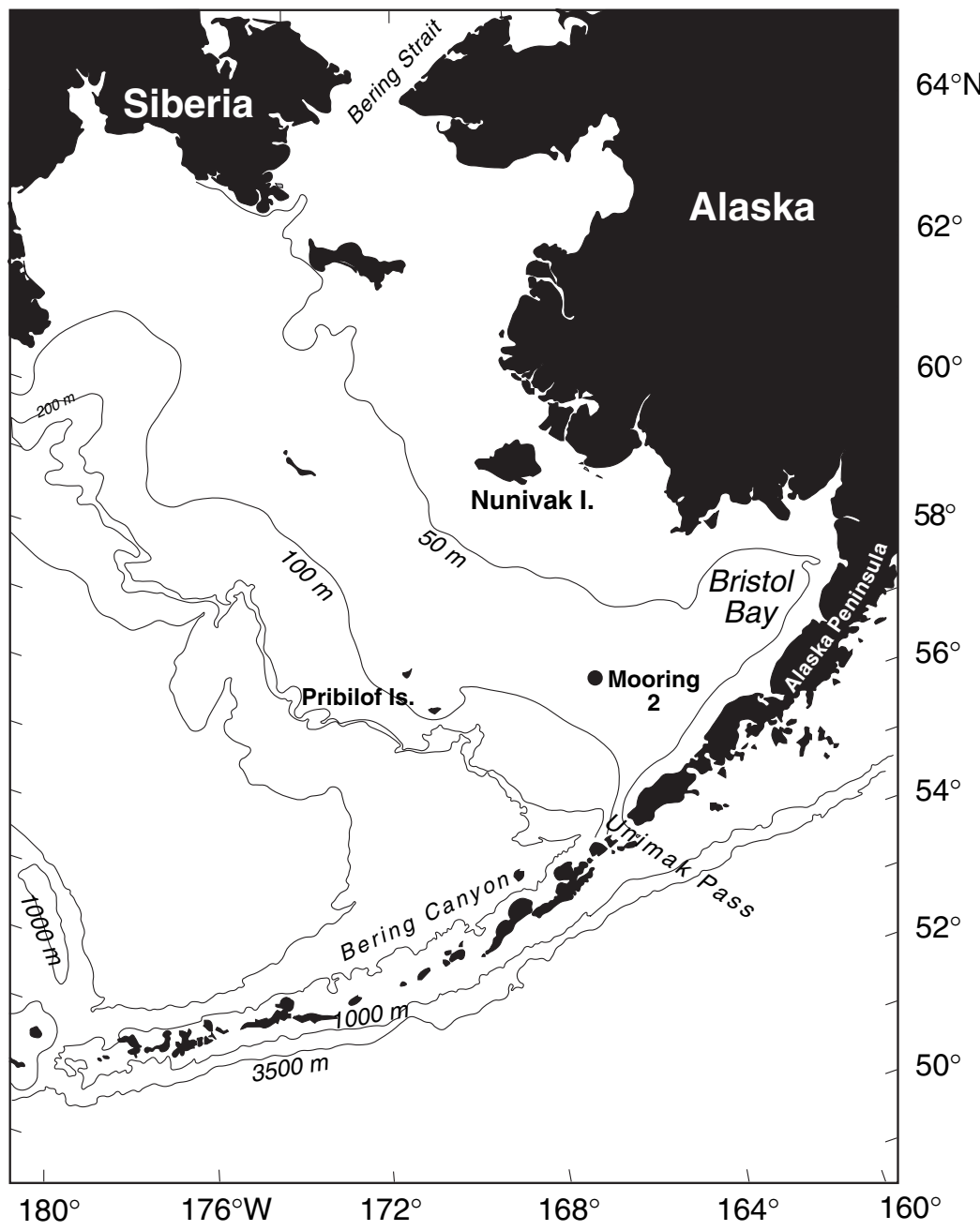

season. Because these types of events appear to dominate the net interannual variability in the physical oceanography, they should also have substantial impacts on the biology.

\section{Walleye pollock (Theragra chalcogramma)}

The recruitment of eastern Bering Sea walleye pollock (Ianelli et al., 2001) varies substantially from year to year (Fig. 2). Our objective is to illustrate how this time series might be linked to the episodic nature of the atmospheric forcing of the Bering Sea. In making this linkage, we consider a previously explored mechanism related to the winter weather and specifically the 'cold pool' of the Bering Sea shelf (e.g. Wyllie-Echeverria and Wooster, 1998), and a more novel mechanism related to summer weather, specifically the magnitude of wind mixing. Pollock recruitment appears to be reduced during years with an enhanced 'cold pool' over the Bering Sea shelf. The cold pool is a lower layer of water below about $2^{\circ} \mathrm{C}$ over a relatively small fraction of any particular 
Figure 2. Yearly values of pollock recruitment (heavy solid line), June-July average wind mixing (thin gray line) and average winter surface temperature (dash-dotted line). The latter represents the ice surface temperature when ice is present, and the SST otherwise, and hence provides a measure of the extent and duration of sea ice.

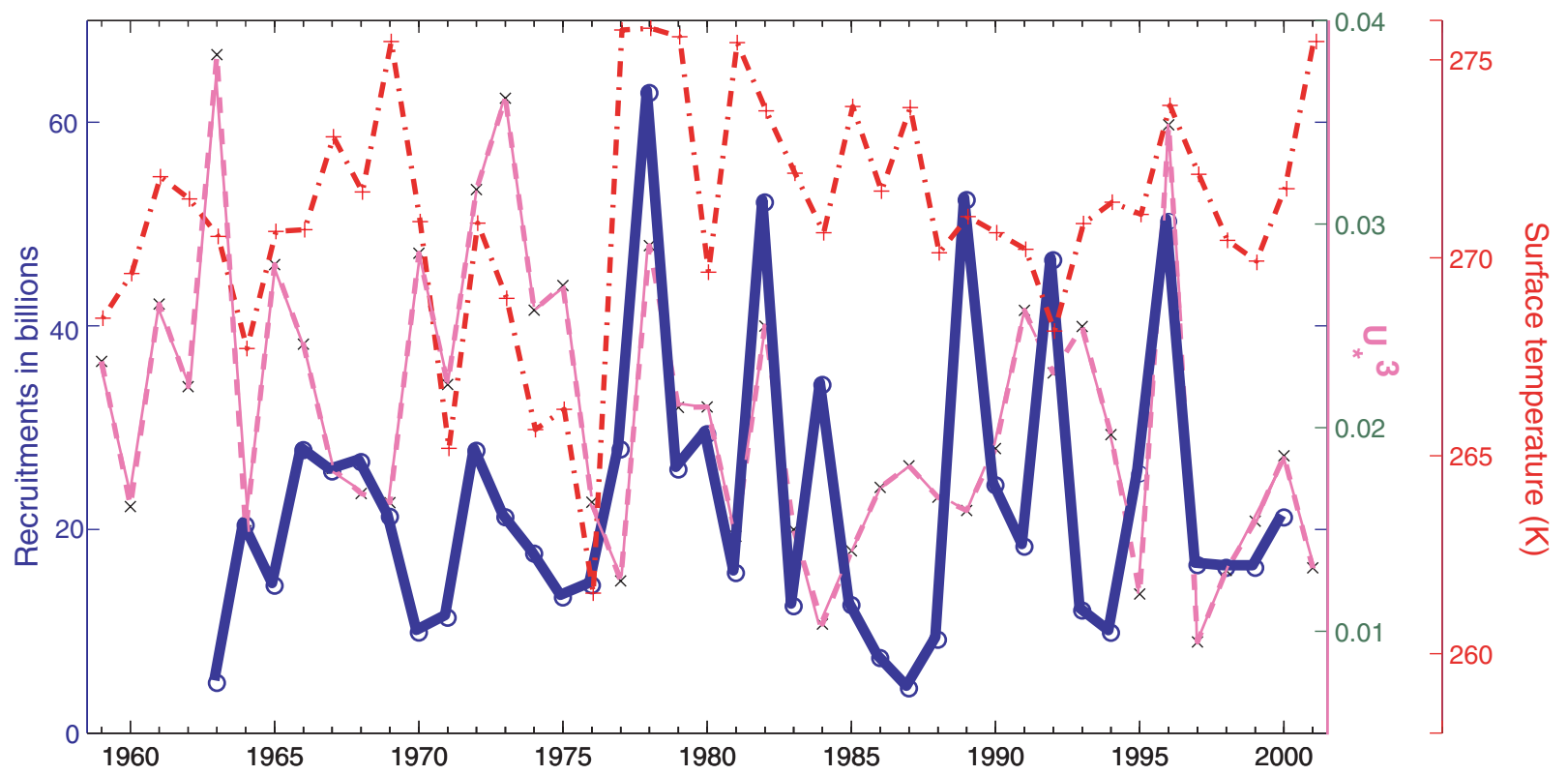

that forms in the marginal ice zone in winter, and persists through spring into summer when insulated from the seasonal heating of the upper mixed layer. The extent of the cold pool appears to be dependent on the coverage and duration of sea ice in winter. A proxy for this ice coverage is represented by the mean surface temperature at Mooring $2\left(57^{\circ} \mathrm{N}, 164^{\circ} \mathrm{W}\right.$; see Fig. 1) for January through March (Bond and Adams, 2002); a time series of this winter index is shown in Fig. 2. As shown in Bond and Adams (2002), cold winters on the whole, such as 1995 and 1997, are caused by a few short-lived arctic-air outbreaks. Figure 2 indicates that there was a marked tendency for heavy ice/cold winters in the early to mid-1970s, as compared with the light ice/warm winters in the late 1970s and 1980s. The preference for warmer winters and hence smaller cold pools in the latter period essentially provided a greater area of suitable habitat for larval and juvenile pollock (Wyllie-Echeverria and Wooster, 1998). This concept helps explain the dearth of high pollock recruitment years prior to the North Pacific climate regime shift of 1976-77. But the yearto-year variability in pollock recruitment after the regime shift appears little related to the severity of the corresponding winters.

After the regime shift, years with high recruitment tend to coincide with years of anomalously strong wind mixing in early summer (Fig. 2). The connection plausibly involves the following processes: enhanced wind mixing at this time of year causes stronger entrainment at the base of the mixed layer (C. Ladd, personal communication), a more sustained supply of nutrients to the euphotic zone (Sambrotto et al., 1986; Whitledge et al., 1986), higher rates of primary productivity and, ultimately, greater availability of preferred prey (e.g. copepod nauplii) of larval pollock after the usual spring bloom.

Because 1978 was the year of record pollock recruitment, and since the winters of 1977 and 1979 were also very warm but lacked high recruitment, it is worthwhile to examine the warm season of this period in some detail. Critical aspects of the air-sea interaction over the shelf in 1978 at the location of Mooring 2 are illustrated in Fig. 3. The SST anomaly actually declined from a value of approximately $2^{\circ} \mathrm{C}$ above normal on 1 May to near normal from mid-July through September (top panel). Much of this decline is associated with greater than normal wind mixing $\left(u_{*}^{3}\right)$ in late June and early July (middle panel), and hence a greater than usual rate of mixing of cold water from below the thermocline, and negative net heat flux anomalies in June (bottom panel). By way of contrast, similar time series for 1979 are shown in Fig. 4. This year lacked prominent storms in June and July, and the net heat fluxes averaged slightly above normal. Consequently, the SST anomalies in 1979 
Figure 3. Daily values at Mooring $2\left(57^{\circ} \mathrm{N}, 164^{\circ} \mathrm{W}\right)$ of sea surface temperature anomaly (C, top panel), wind mixing or $u_{*}^{3}$ $\left(\mathrm{m}^{3} \mathrm{~s}^{-3}\right.$, middle panel), and net surface heat flux at $56^{\circ} \mathrm{N}, 172^{\circ} \mathrm{W}\left(\mathrm{W} \mathrm{m}{ }^{-2}\right.$, bottom panel) from the NCEP/NCAR Reanalysis for May-September 1978. The dotted lines represent climatological means (1959-99).
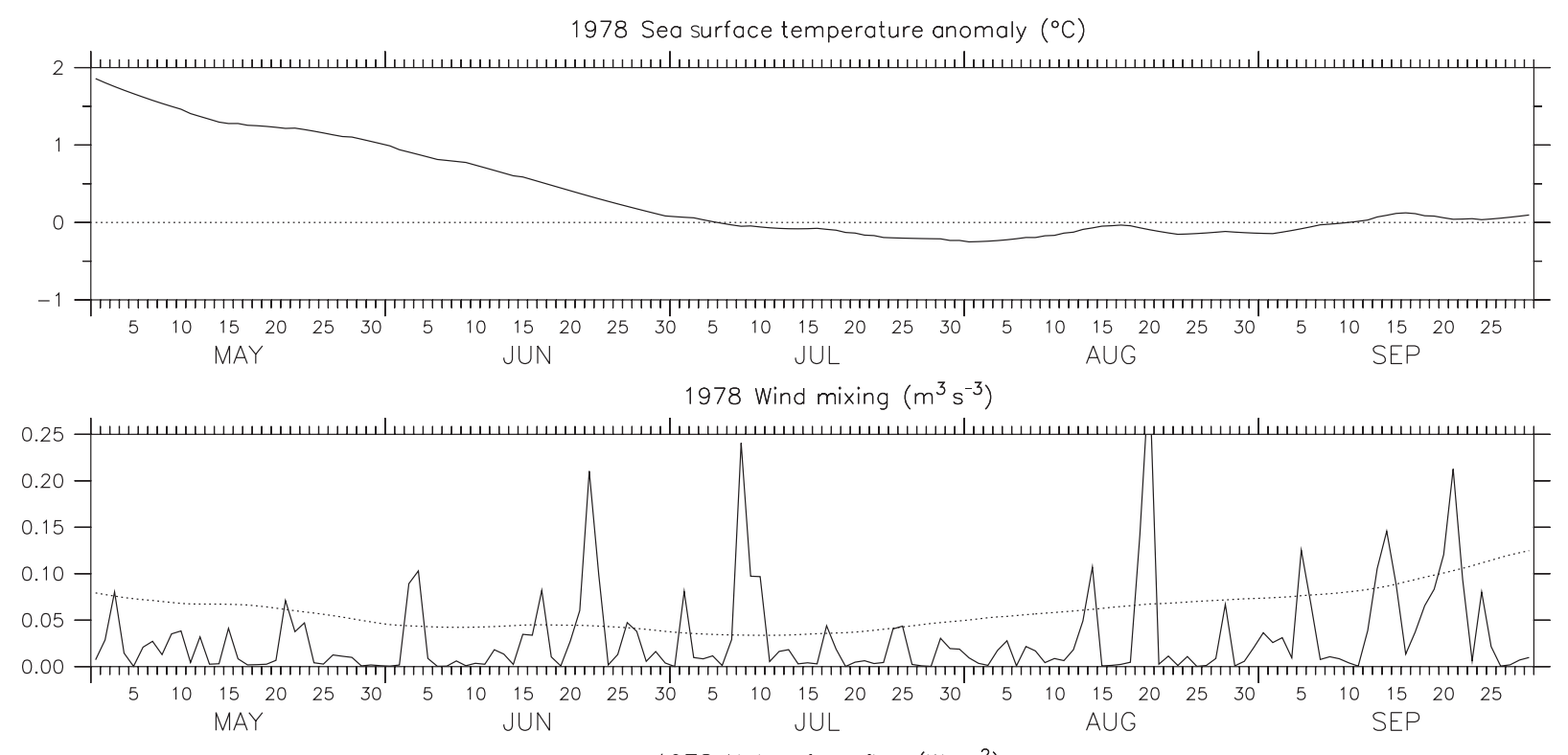

1978 Net surface flux $\left(\mathrm{W} \mathrm{m}^{-2}\right)$

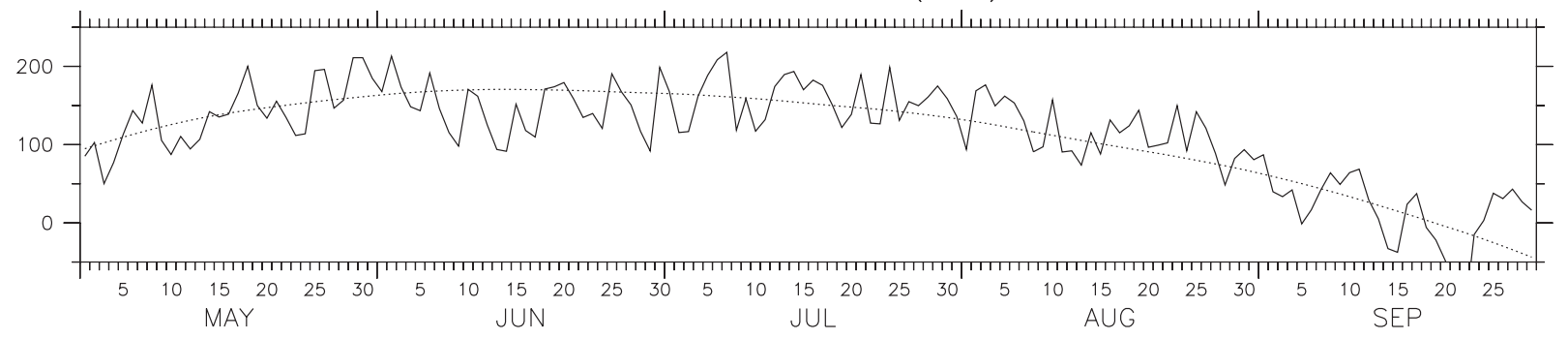

remained about plus $1^{\circ} \mathrm{C}$. There were conductivitytemperature-depth (CTD) surveys carried out in the vicinity of Mooring 2 in the summers of 1977-79; vertical cross-sections of temperature from CTD lines are shown for 1978 (Fig. 5; top) and 1979 (Fig. 5; bottom). As expected given the differences in atmospheric forcing, the mixed layer was considerably deeper $(\sim 30 \mathrm{~m})$ in 1978 than in $1979(\sim 20 \mathrm{~m})$. Additional evidence for enhanced entrainment in 1978 is provided by the similarity in near-surface temperatures from the two CTD cross-sections. The section in 1978 was collected 4 weeks later than its counterpart in 1979; greater mixing of cold water from depth appears to have counteracted the seasonal warming in the former year. The sharper thermocline in 1978 than in 1979 is consistent with more mixing from above and hence greater homogenization of the upper part of the water column. The very cold bottom water (which is tidally mixed) effectively represents a floor to which this mixing extends. We emphasize that the anomalous wind mixing in 1978 on the whole
(Fig. 2) was due to the effects of a few bursts of especially strong winds (Fig. 3).

Enhanced monitoring of the Bering Sea has been carried out since the mid-1990s, and in one of those years, 1996, there were conditions closely resembling those of 1978. First, 1996 was a light ice year, as implied by the winter surface temperature time series in Fig. 2. Time series of the daily forcing in the spring and summer of 1996 (Fig. 6) show that enhanced winds and suppressed surface heating occurred in June of that year. The data from Mooring 2 (Stabeno et al., 2001; their Fig. 8) show that the early summer of 1996 featured a relatively deep and cool mixed layer, and substantial fluorescence due to chlorophyll well into July past the time of the usual spring bloom. Recruitment of pollock in 1996 was also estimated to have been at the highest level since 1989 (Ianelli et al., 2001).

While four out of the five years with the greatest pollock recruitment since 1977 have included a windy summer (1989 was the exception), there are additional 
Figure 4. As in Fig. 1, but for 1979.

1979 Sea surface temperature anomaly $\left({ }^{\circ} \mathrm{C}\right)$

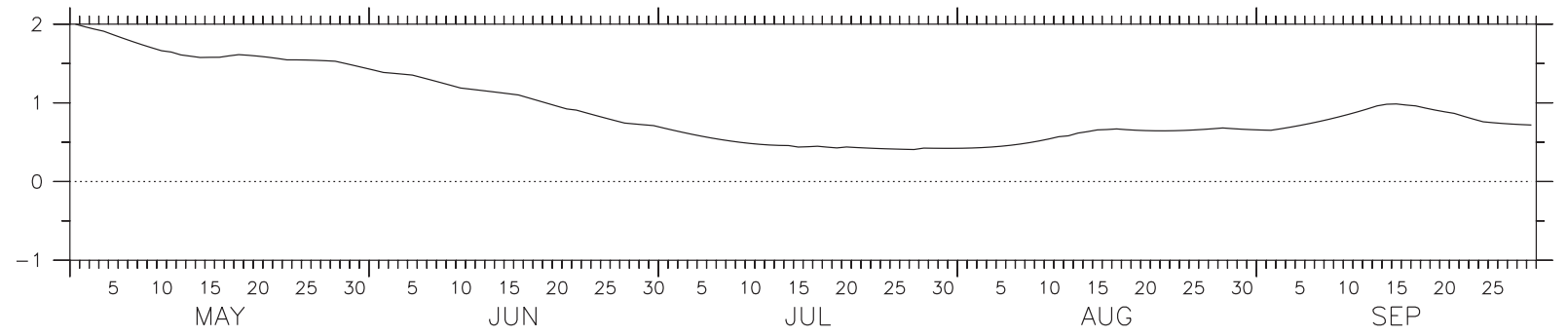

1979 Wind mixing $\left(\mathrm{m}^{3} \mathrm{~s}^{-3}\right)$

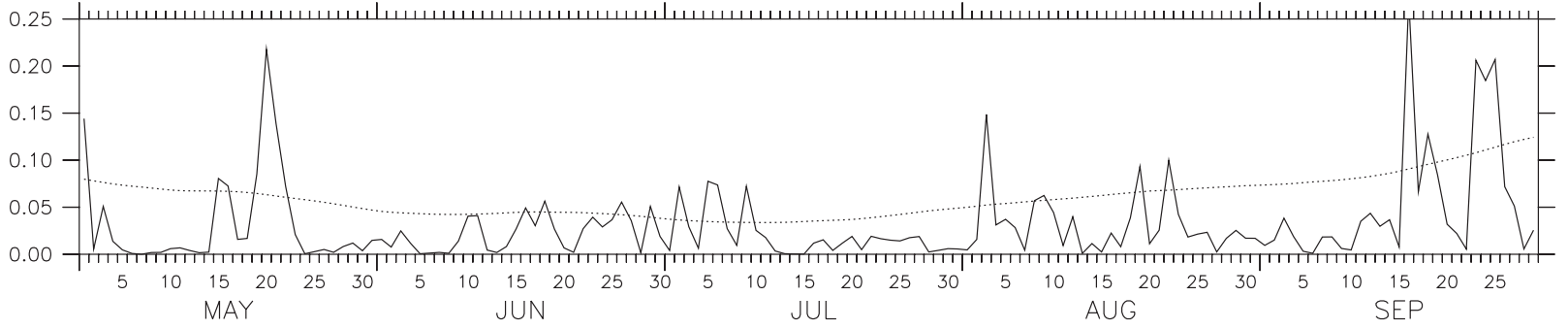

1979 Net surface flux $\left(\mathrm{W} \mathrm{m}^{-2}\right)$

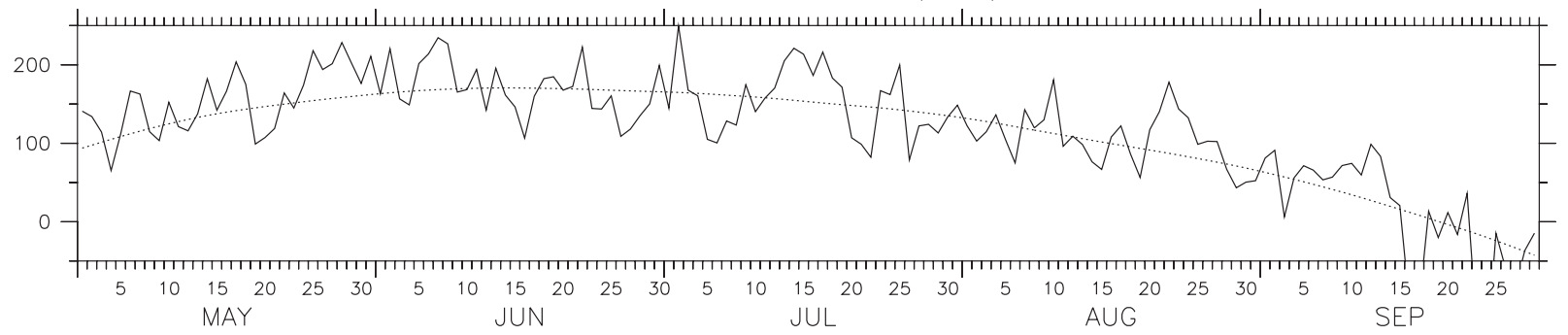

physical mechanisms that potentially influence pollock recruitment. For example, variations in crossshelf transport during spring (April through June) appear to be related to recruitment (Wespestad et al., 2000). With regards to the conditions in spring, Bailey et al. (1986) postulated that weak wind mixing and anomalously warm near surface temperatures during March through May of 1978 promoted zooplankton development and hence relatively high prey concentrations for larval pollock in spring of that year. For both these examples, just as for winter ice or summer mixing, the presence or lack of strong forcing events is crucial.

Our analysis related to walleye pollock yields two important points: substantial subseasonal atmospheric variability occurs throughout the year in the eastern Bering Sea, and episodic weather phenomena tend to dominate the net atmospheric forcing in any one season. Our examination of the historical record also suggests the hypothesis that the co-occurrence of warm winters and windy summers favors high pollock recruitment.

\section{Tanner crabs (Chionoecetes bairdi)}

The early 1980s represented a favorable period for young Tanner crabs over the south-east Bering Sea shelf, as documented by Rosenkranz et al. (2001). They argued that the relatively high recruitment is likely to be attributable to northeast wind anomalies during the spring, and hence enhanced offshore directed Ekman transport on the north side of the Alaska Peninsula. Transports of this sense should favor Tanner crabs in two ways: by advecting larvae into suitable habitats featuring fine sediments, and by increasing coastal upwelling and hence the overall productivity of the southern portion of the shelf. Their time series show that Tanner crab recruitment was particularly high for the 1981 and 1984 year-classes. We seek to determine whether there were aspects of the physical environment that are especially notable for those years. The tacit assumption is that the variability in mortality is greatest during Tanner crabs' first spring and summer, and that their feeding conditions at that time strongly determine year-class strength. In 
Figure 5. Vertical cross-section of temperature from a conductivity-temperature-depth survey near Mooring 2 in the middle shelf domain of the Bering Sea shelf in July 1978 (top) and June 1979 (bottom). Solid lines are isotherms in whole degrees; dashed lines indicate intermediate values. The lower solid line refers to the bottom bathymetry. The small triangles at the bottom indicate sounding locations.
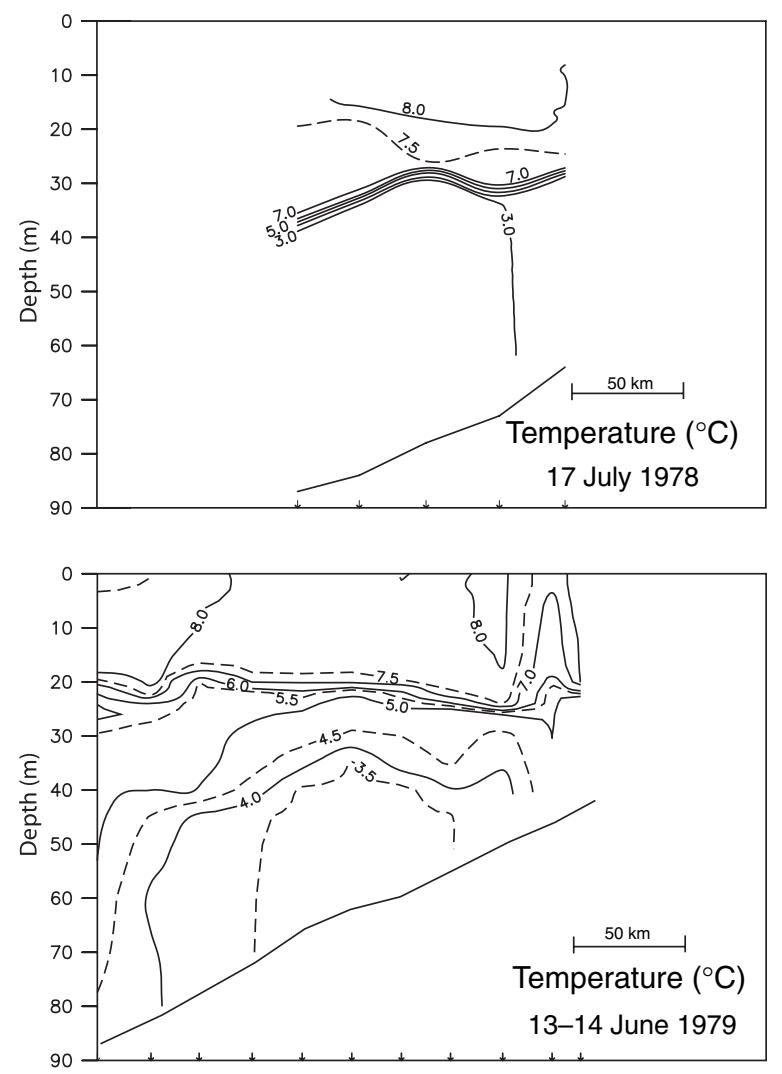

analysis of the physical control of these feeding conditions, we do not restrict ourselves to just spring and early summer, but instead also consider preceding winters. In particular, we expect that wintertime airsea interactions may be important to the benthic community of the southern Bering Sea shelf through modulation of the transport through Unimak Pass at the end of the Alaska Peninsula (Fig. 1).

Unimak Pass may represent a primary source of new nutrients for the Bering Sea shelf. The flow through Unimak Pass tends to be northward, and a portion of this flow advects eastward onto the shelf. The water in the Pass is relatively rich in nutrients due to tidal mixing of deep water out of Bering Canyon (Stabeno et al., 2002). The flux of nutrients through Unimak Pass may be important because about one-half of the nitrogen supporting the ecosystem of the shelf appears to be replenished each year (Stabeno et al., 2002). Enhanced northward transport through Unimak Pass occurs during times of easterly wind anomalies along the Alaska Peninsula. Winds of this sense tend to constrain the Alaskan Coastal Current (ACC) against the shelf break on the south side of the Alaska Peninsula, which in turn leads to greater flow through Unimak Pass (Schumacher et al., 1982), as observed by Stabeno et al. (2002) and modeled by Nof and Im (1985).

Our objective is to examine the character of the wind forcing of transport through Unimak Pass, and whether the variability in these winds is plausibly related to interannual variability in Tanner crab recruitment during the early 1980s. As in the previous section, this analysis includes illustration of the dayto-day forcing in selected individual years, and seasonal composites for the entire record.

Time series of daily along-peninsula wind stresses at Unimak Pass $\left(54^{\circ} \mathrm{N}, 165^{\circ} \mathrm{W}\right)$ for November through June of 1981-84 are shown in Fig. 7. Note that the day-to-day variability is generally much greater in the cool season than after April. If the transport of nutrients through Unimak Pass is indeed an important factor for nutrient concentrations over the shelf north of the Pass, then it is reasonable that variability in winter is paramount. These time series also show that winter winds are highly episodic, but with somewhat longer time scales than individual storms. Notable wind stress anomalies tend to last roughly a week or two, for example, the two intense easterly events of December 1980 (Fig. 7, top panel), and anomalies of a particular sense rarely last longer than a month.

Seasonal averages of the components of the atmospheric forcing hypothesized to impact the recruitment of Tanner crabs are plotted in Fig. 8. This plot includes three sets of parameters: (1) the mean along-Peninsula wind stress at $54^{\circ} \mathrm{N}, 165^{\circ} \mathrm{W}$ for May-June and November-April (bottom panel), (2) the mean January-March surface temperature at Mooring 2 (top panel) because this parameter relates to bottom temperatures in the following warm season which in turn impacts gonadal development and timing of mating and ultimately the development of viable embryos (Rosenkranz et al., 2001), and (3) the January-March cross-shelf wind stress and net surface heat flux at Mooring 2 (middle panel) because of their relationship to near-surface flow and sea ice, respectively. These time series reveal that 1981 and 1984 are distinguished by the occurrence of relatively large wind stresses from the east-north-east (negative values in Fig. 8, bottom panel) in both winter (November-April) and spring (May-June). Therefore, those years featured not only enhanced upwelling in spring, but also enhanced forcing of 
Figure 6. As in Fig. 3, but for 1996.

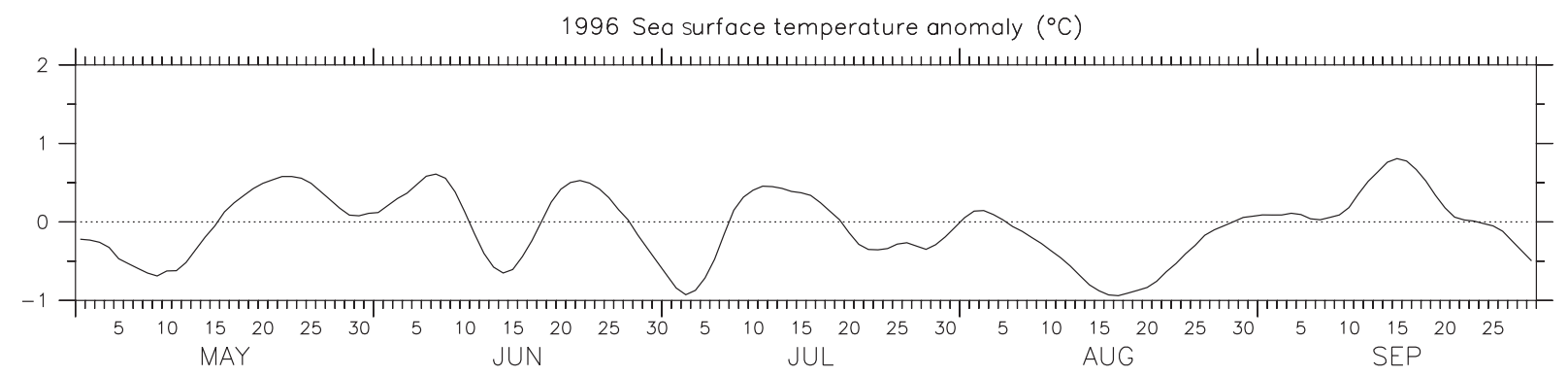

1996 Wind mixing $\left(\mathrm{m}^{3} \mathrm{~s}^{-3}\right)$

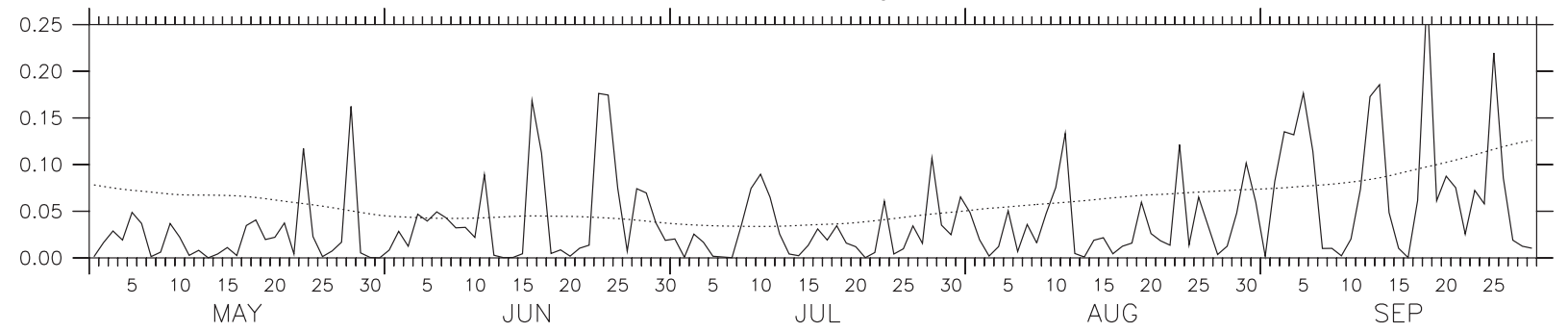

1996 Net surface flux $\left(\mathrm{W} \mathrm{m}^{-2}\right)$

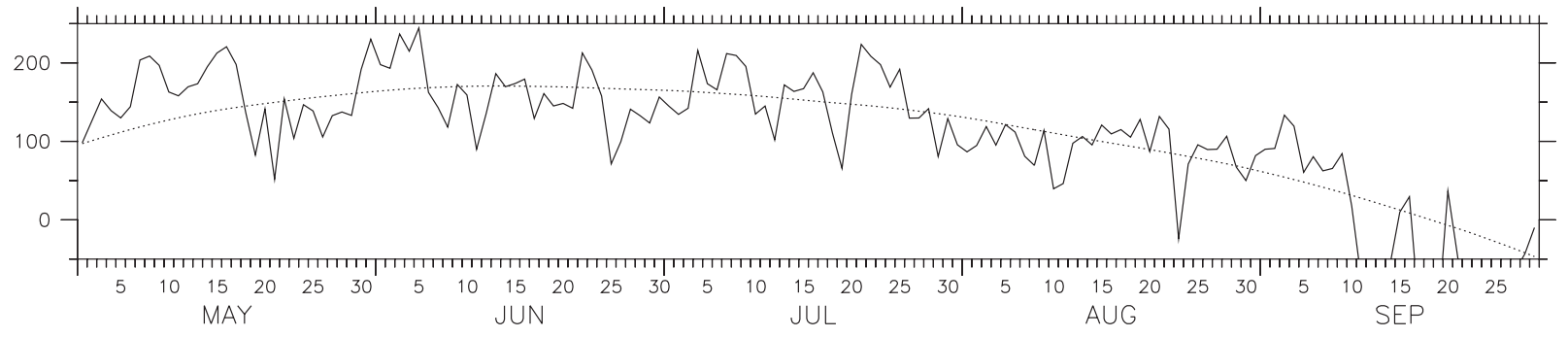

northward transport through Unimak Pass in winter. The along-Peninsula winds were relatively unfavorable in 1982, and indeed relatively poor recruitment has been diagnosed for that year as compared with the early 1980s in general. The period of 1977-87 included warmer than normal winters, which as mentioned above, promotes development of Tanner crab embryos. While 1992 had favorable along-Peninsula winds in winter and spring, by the measure used here it represented the sixth coldest winter since 1959. Hence while feeding conditions might have been good, the number of embryos was probably low, and hence 1992 would not be expected to have had a strong year-class of Tanner crabs. It is interesting to note that recent winters (late 1990s to 2001), as compared with the long-term climatological mean, have included cross-shelf winds to be directed more onshore and, for net surface heat fluxes to cause less cooling, both of which promote less sea ice and warmer bottom temperatures. Of these years, the along-Peninsula winds for winter and spring com- bined appear to be most advantageous for Tanner crabs hatched in 2000.

The winter and spring/summer winds along the Alaska Peninsula impact the water properties over the shelf north of the Peninsula in different ways. As the water column is well-mixed in the winter due to the seasonal cooling and vigorous winds, an important impact of the wind variability at this time of year is to modulate the transport through Unimak Pass and ultimately, the horizontal flux of nutrients onto the shelf. During late spring and summer, the water column becomes more stratified, coastal upwelling becomes a more important process, and hence the wind variability may be more instrumental in modulating the vertical flux of nutrients. If the water north of the Alaska Peninsula is only weakly replenished subsequent to the previous warm season's draw down of nutrients, the column-averaged nutrient levels going into the warm season should tend to be low, to the detriment of the overall primary productivity even in years of upwelling-favorable winds. 
Figure 7. Daily values of the along-peninsula wind stress $\left(\mathrm{N} \mathrm{m}^{-2}\right)$ at Unimak Pass $\left(54^{\circ} \mathrm{N}, 165^{\circ} \mathrm{W}\right)$ for November through June of 1980-81, 1981-82, 1982-83 and 1983-84. Positive values imply winds from the west. The dotted lines represent climatological means (1959-99).

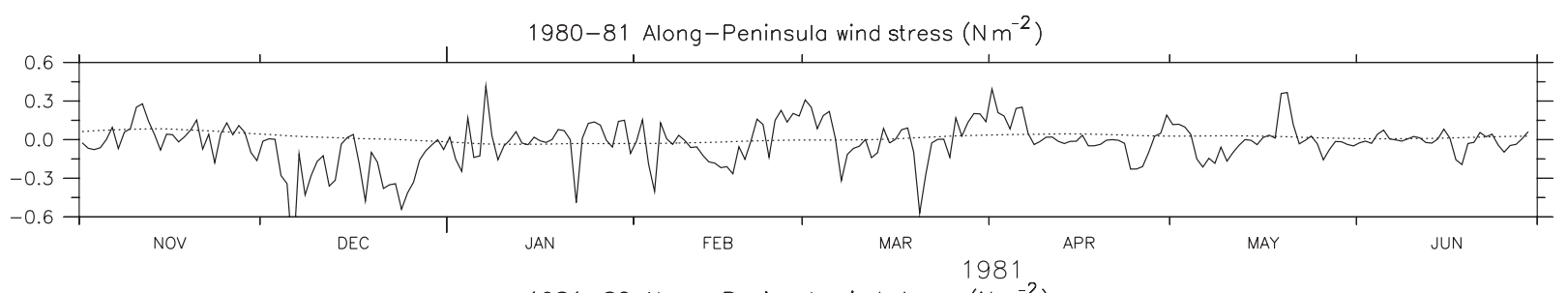

1981-82 Along-Peninsula wind stress $\left(\mathrm{Nm}^{-2}\right)$

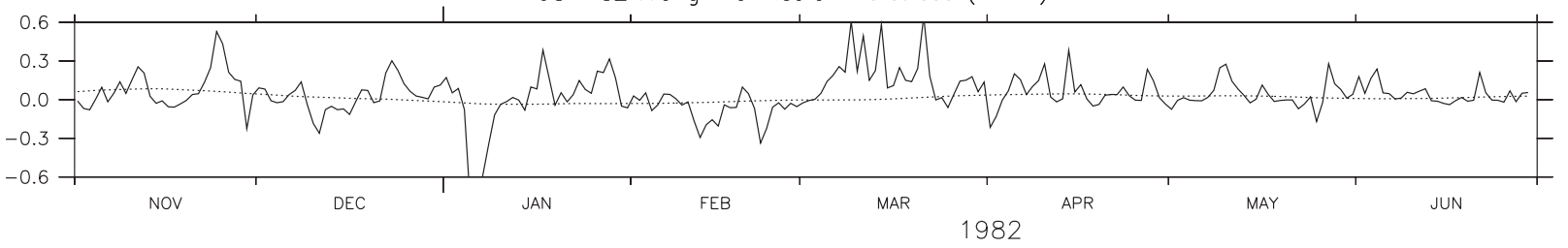

1982-83 Along-Peninsula wind stress $\left(\mathrm{N} \mathrm{m}^{-2}\right)$
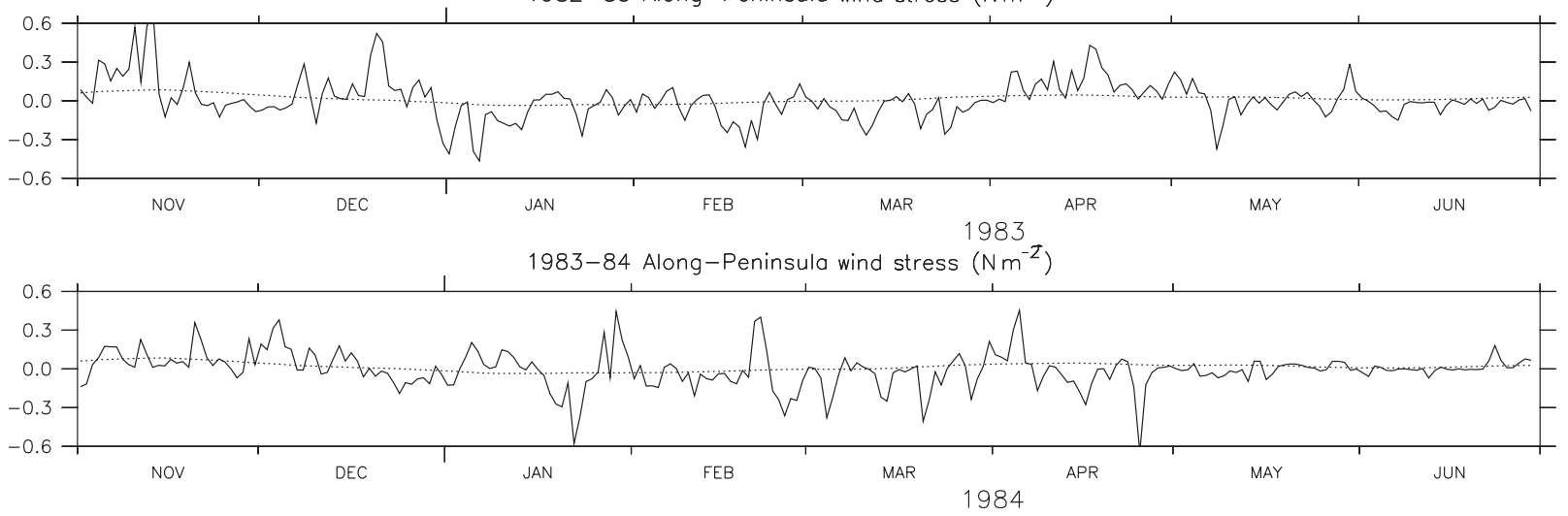

It is interesting that the two best years for Tanner crabs, 1981 and 1984, included pollock recruitment that was well-below average and slightly higher than average, respectively (Fig. 2; Ianelli et al., 2001). One possible explanation for the discrepancy in success is that the bulk of the age- 0 pollock larvae over the southeast Bering Sea shelf are well north of the Alaska Peninsula in early summer (Bailey et al., 1999). We expect that it is primarily the region within roughly 100$200 \mathrm{~km}$ north of the Peninsula that responds to interannual variations in the flow through Unimak Pass.

In summary, while overall biophysical conditions were relatively favorable for Tanner crabs in the early 1980s, larval survival seems to have been particularly good in 1981 and 1984. Those were the only two years from the late 1970s through the 1980s during which winter and spring wind anomalies promoted both flow through Unimak Pass and coastal upwelling on the north side of the Alaska Peninsula. It bears emphasizing that these wind anomalies for the season were actually associated with a few, prominent events lasting on the order of a week to a month.

\section{Coccolithophorid phytoplankton (Emiliania huxleyi)}

The first documented bloom of a coccolithophorid phytoplankton (Emiliania huxleyi) occurred over the Bering Sea shelf in the summer of 1997 (Vance et al., 1998). Previous studies (notably Napp and Hunt, 2001; Stockwell et al., 2001) have considered the conditions that occurred in 1997 that seem to have favored this species. There appear to have been two key aspects of the weather that year. First, a prominent storm occurred in middle to late May. This storm was unusual for its strength $\left(20 \mathrm{~m} \mathrm{~s}^{-1}\right.$ wind speeds) and duration (2-3 days) for the season. It caused vigorous vertical mixing over the shelf and served to stimulate a bloom after an ice-edge bloom earlier in the spring. The net effect of the storm was to help strip the nitrate and silicate from the water column below the thermocline over the Middle and Inner Shelf Domains (Stockwell 
Figure 8. Season averages for $1959-2001$. Top: surface temperature at $57^{\circ} \mathrm{N}, 164^{\circ} \mathrm{W}$ (solid line, ${ }^{\circ} \mathrm{C}$ ). Middle: cross-shelf wind stress at $57^{\circ} \mathrm{N}, 164^{\circ} \mathrm{W}$ (solid line, $\mathrm{N} \mathrm{m}^{-2}$ ) and net surface heat flux (dotted line, $\mathrm{W} \mathrm{m}^{-2}$ ). Bottom: along-peninsula wind stress at $54^{\circ} \mathrm{N}, 165^{\circ} \mathrm{W}$ during spring (solid line, $\mathrm{N} \mathrm{m}^{-2}$ ) and winter (dotted line, $\mathrm{N} \mathrm{m}^{-2}$ ).
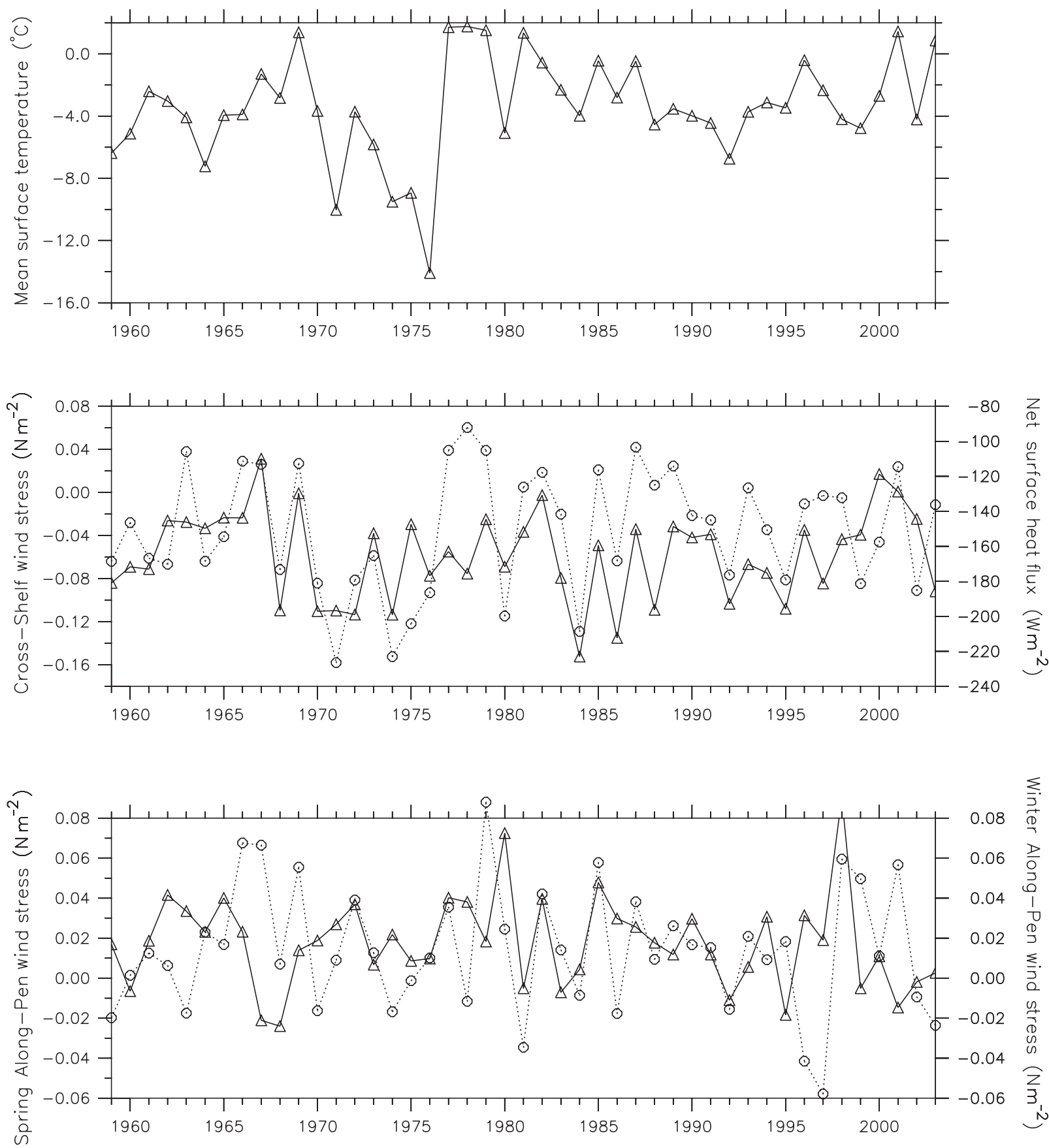

et al., 2001). Secondly, the weather following the May storm was unusually calm and sunny (Overland et al., 2001). These conditions promoted the development of a relatively warm and shallow mixed layer and, perhaps more importantly, an anomalously large temperature difference across the thermocline, from June to August
(Stabeno et al., 2001). Therefore the summer of 1997 featured both suppressed vertical mixing across the thermocline, and reduced nutrient levels in that water that was mixed up from below (e.g. Stockwell et al., 2001), and consequently, extremely low nutrient concentrations in the upper mixed layer over the shelf. 
Figure 9. Daily values of sea surface temperature tendency $\left({ }^{\circ} \mathrm{C}\right.$ per 10 days, top panel), wind mixing $\left(u_{*}^{3}\right)\left(\mathrm{m}^{3} \mathrm{~s}^{-3}, \mathrm{middle}^{-}\right.$ panel), and downward shortwave flux (W m ${ }^{-2}$, bottom panel) at Mooring $2\left(57^{\circ} \mathrm{N}, 164^{\circ} \mathrm{W}\right)$ for May-September 1997 . The dotted lines represent climatological means (1959-99).
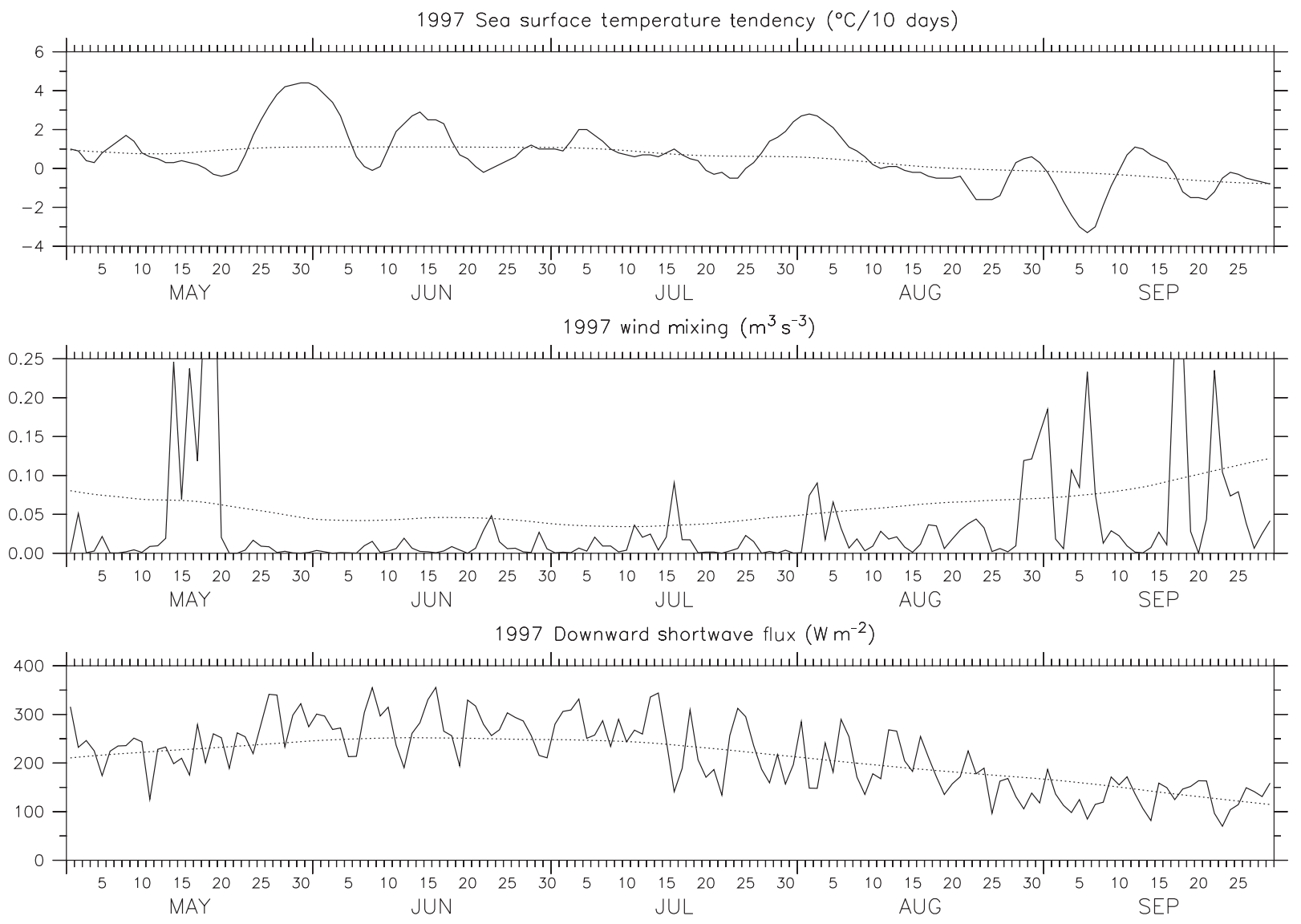

The warm, nutrient-poor mixed layer appears to have provided Emiliania huxleyi a competitive advantage versus other members of the phytoplankton community such as diatoms.

Our objective is to inspect the day-to-day weather that occurred during the spring and summer of 1997 in a manner similar to that in the previous two sections, but considering somewhat different air-sea interaction parameters. Specifically, time series of daily averaged values of the net surface heat flux, the downward short wave irradiance (insolation), and wind mixing $\left(u_{*}^{3}\right)$ during 1997 are shown in Fig. 9. These time series show anomalous solar heating of the water column at a rate of roughly $50 \mathrm{~W} \mathrm{~m}^{-2}$ from late May into early July. This component dominated both the mean and dayto-day variations in the net heating. The time series also reveal that this anomalous heating was interrupted once a week or so by a day or two of anomalous cooling. The point to be made here involves a hierarchy of time scales. The actual anomalous warming events occurred on time scales of typically 4-7 days, and these events were favored during a period lasting about 2 months. Yet these events were sufficient to produce a quite unusual summer over the Bering Sea shelf.

The extent to which 1997 was unusual can be gauged through consideration of the 40-yr historical record. Here we consider both the spring and early summer, since it is expected that it was their combined effects that led to the prominent coccolithophorid bloom. The parameters considered (Fig. 10) are May and June-July wind mixing (bottom panel), June-July net surface heat fluxes and June-July heating below the mixed layer (middle panel), and June 1 SST and June-July SST tendency (top panel). The heating below the mixed layer (middle panel of Fig. 10) is estimated to be the amount of the net surface heating remaining after warming $20 \mathrm{~m}$ of water (a typical depth of the mixed layer) at the rate of the change in SST. This estimate neglects horizontal temperature advection and variations in mixed layer depth; the 
Figure 10. Summer season averages for $1959-2001$ at Mooring $2\left(57^{\circ} \mathrm{N}, 164^{\circ} \mathrm{W}\right)$. Top: sea surface temperature on June 1 (solid line, ${ }^{\circ} \mathrm{C}$ ) and sea surface temperature tendency for June-July (dotted line, ${ }^{\circ} \mathrm{C}$ per 100 days), both at $57^{\circ} \mathrm{N}, 164^{\circ} \mathrm{W}$. Middle: net heat flux for June-July (solid line, $\mathrm{W} \mathrm{m}^{-2}$ ) and heating below mixed layer in June-July (dotted line, $\mathrm{W} \mathrm{m}^{-2}$ ). Bottom: wind mixing in May (solid line, $\mathrm{m}^{3} \mathrm{~s}^{-3}$ ) and wind mixing in June-July (dotted line, $\mathrm{m}^{3} \mathrm{~s}^{-3}$ ).
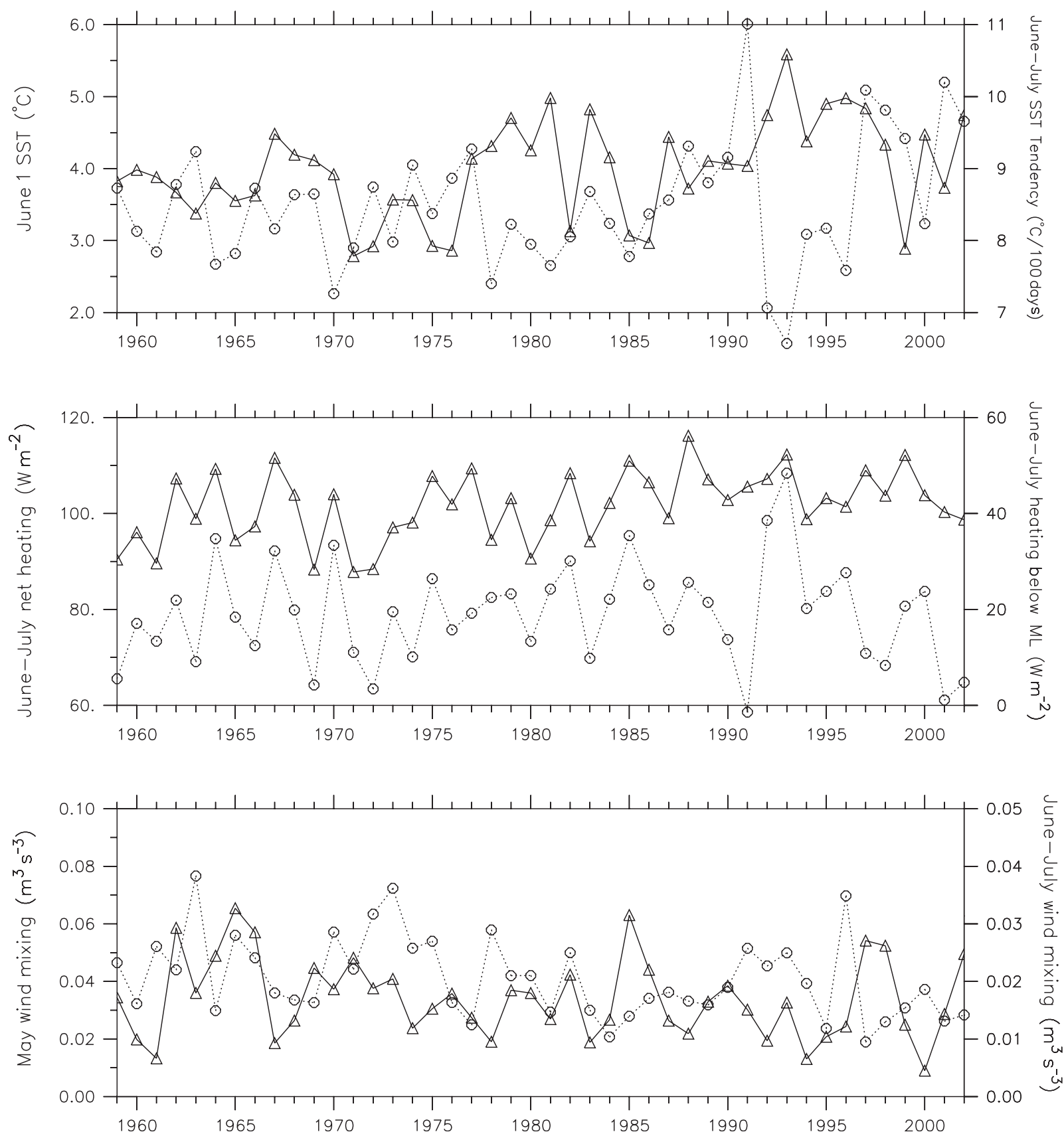

neglect of these factors is justified in estimating the heating below the mixed layer on the basis of Reed and Stabeno (2002) and Stabeno et al. (2001), respectively. Essentially, the greater the difference between estimated heating below the mixed layer and the net surface heat fluxes, the greater the thermal stabilization at the thermocline. While the static stability of the water column is also dependent on the vertical profile of salinity, by the end of summer the year-to-year variability in stratification is largely controlled by the temperature profile (Stabeno et al., 2001; their Fig. 7b). At first glance, the year of 1997 
may not seem to stand out in the time series plotted in Fig. 10. Further scrutiny reveals that the June-July wind mixing was the lowest overall on record, and that these calm conditions followed the second windiest May, on average, since the mid-1960s. In addition, the June-July heating at the surface was more than usual while the heating below the mixed layer was less than usual. While neither anomaly was extreme, the key aspect here may be that their difference was the second largest in the record, only exceeded by that found for 1991. Finally, not only was the June-July SST tendency well above average in 1997, i.e. the thirdhighest on record, due to anomalous heating and calm winds, but, as revealed by the SST time series for June 1, it started off warmer than normal. Previous years with warmer than normal SSTs on June 1 tended to also include weak-to-average rates of SST warming for the following two months. It is interesting to note that the closest analog to 1997 was 1998. The continuation of warm conditions in the Bering Sea, and implied anomalous upper ocean stratification during the summertime, presumably served to further establish the coccolithophores in the marine ecosystem of the Bering Sea shelf. Large patches of high concentrations of coccolithophores continued to be found from 1999 through 2000 (J. Napp, Alaska Fisheries Science Center, Seattle, WA, USA, personal communication), although summertime conditions were not that advantageous. The persistence of the coccolithophorid bloom has been attributed to reduced microzooplankton grazing rates (Olson and Strom, 2002).

\section{DISCUSSION}

The purpose of this article is to suggest the importance of major short-term (intraseasonal) weather events to longer time-scale ecosystem variations on the Bering Sea shelf. We hasten to add that multi-year climate variations are still important directly through their impact on gyre-scale ocean circulations, and indirectly and perhaps most significantly through their influences on probability density functions (PDFs) of shorterterm weather phenomena. An example of this type is the effects of the PDO on arctic-air outbreaks that were favored during the 1960s and early 1970s, and suppressed during the late 1970s and 1980s, with impacts on sea-ice coverage and, ultimately, walleye pollock. We recognize that our analysis is heuristic and inferential, in that it links causes and effects without strong in situ evidence of biological aspects of these linkages. While the hypotheses concerning biophysical interactions may be incomplete, aspects of the intraseasonal weather variability are significant and, in particular situations, seem to be crucial to the ecosystem of the Bering Sea shelf.

Our results raise specific questions related to biophysical mechanisms involving the three target species. With regard to walleye pollock, it is uncertain whether they are actually food limited in the larval stage. Napp et al. (1998) indicate that the linkages between primary production, secondary production, and larval condition is anything but straightforward. Addressing this issue more completely would require improved knowledge of the timing of primary production as a function of depth and its effects on elements of the zooplankton assemblage preferred by pollock (Napp et al., 2002). Concerning Tanner crabs, there exists only primitive understanding of the fate of the water transported northward through Unimak Pass, especially in winter, and its interactions with the Aleutian North Slope Current (ANSC). In other words, our speculations concern not just biophysical mechanisms, but also the basic physical oceanography in the region of interest. The coccolithophorid bloom of 1997 was truly remarkable. While the weather that late spring and summer was highly unusual, at least similar temperature, stratification, and nutrient profiles are expected to have occurred in the past. It is unclear the extent to which the bloom can be attributed to these profiles exceeding a threshold or because of additional biological factors. We hope our analysis encourages the fisheries oceanography community to further investigate these and related issues.

Progress warrants using a hierarchy of physical ocean models to examine local and large-scale air-sea interactions, and numerical and conceptual biophysical models to elucidate specific mechanisms. These studies should help indicate the sensitivities in the variety of linkages between the physical environment and the ecosystem. Our analysis indicates that some critical biophysical processes occur over short time scales and, presumably, on small spatial scales.

An important implication of our paradigm involving the importance of episodic weather events relates to the predictability of the marine ecosystem. Deterministic weather forecasts are viable out to roughly 10 days based on NWP models. Much less skillful, but still useful, outlooks for seasons as a whole are produced using statistical and NWP tools to account for the probable influences of slow-changing boundary conditions (e.g. SST and snow/ice cover). Intraseasonal (weekly to monthly) variability falls between those two ranges. The weather on these time scales is stochastic, and its predictability is limited. In the foreseeable future there may be the capability to anticipate changes in the PDFs of extreme 
intraseasonal events, but it is unlikely that these events will be explicitly predicted with long lead times. Assuming intraseasonal aspects of the atmospheric forcing are critical to the marine ecosystem, the predictability of adjustments or shifts in the ecosystem will be limited to changes in the probability of these adjustments, rather than specific forecasts in time and place.

On the contrary, there are benefits, once the linkages between the physical forcing and the biological response are sufficiently understood. Through monitoring of key aspects of the marine ecosystem of the shelf, we may eventually be able to deduce significant changes or trends in near real time, and not be constrained to wait years to decide whether a decadalscale 'regime shift' has occurred.

\section{ACKNOWLEDGEMENTS}

We thank Chris Baier, Kevin Bailey, George Hunt, Jeff Napp, Jim Schumacher and Phyllis Stabeno for useful discussions. This research was sponsored by the NOAA Coastal Ocean Program through south-east Bering Sea Carrying Capacity and is contribution S476. Our research was also supported by NOAA's Steller Sea Lion Coordinated Research Program and NASA's Office of Polar Programs. This publication is [partially] funded by the Joint Institute for the Study of Atmosphere and Ocean (JISAO) under NOAA Cooperative Agreement No. NA17RJ11232, Contribution No. 967. This is Pacific Marine Environmental Laboratory Contribution No. 2543.

\section{REFERENCES}

Adams, J.M., Bond, N.A. and Overland J.E. (2000) Regional variability of the Arctic heat budget in fall and winter. $J$. Clim. 13:3500-3510.

Bailey, K., Francis, R. and Schumacher, J. (1986) Recent information on the causes of variability in recruitment of Alaska pollock in the eastern Bering Sea: physical conditions and biological interactions. Intl. N. Pacific Fish. Comm. Bull. 47:155-165.

Bailey, K.M., Powers, D.M., Quattro, J.M. et al. (1999) Population ecology and structural dynamics of walleye pollock (Theragra chalcogramma). In: Dynamics of the Bering Sea. T.R. Loughlin \& K. Ohtani (eds). University of Alaska Sea Grant, Fairbanks, AK, AK-SG-99-03, pp. 581-614.

Bond, N.A. and Adams, J.M. (2002) Atmospheric forcing of the southeast Bering Sea Shelf during 1995-99 in the context of a 40-year historical record. Deep-Sea Res. II Top. Stud. Oceanogr. 49:5869-5887.

Bond, N.A., Overland, J.E. and Turet, P. (1994) Spatial and temporal characteristics of the wind forcing of the Bering Sea. J. Clim. 7:1119-1130.

Hare, S.R., and Mantua, N.J. (2000) Empirical evidence for North Pacific regime shifts in 1977 and 1989. Prog. Oceanogr. 47:103-145.
Hunt, G.L., Stabeno, P.J., Walters, G. et al. (2002) Climate change and control of the southeastern Bering Sea pelagic ecosystem. Deep-Sea Res. II Top. Stud. Oceanogr. 49:5821-5853.

Ianelli, J.N., Fritz, L., Honkalehto, T., Williamson, N. and Walters, G. (2001) Bering Sea-Aleutian Islands walleye pollock assessment for 2002. In: Stock Assessment and Fishery Evaluation Report for Groundfish Resources of the Bering Seal Aleutian Islands Regions, Vol. 1. Anchorage, AK: North Pacific Fisheries Management Council, Sec. 1, pp. 1-79.

Kalnay, E., et al. (1996) The NCEP/NCAR 40-year reanalysis project. Bull. Am. Meteorol. Soc. 77:437-471.

Ladd, C. and Bond, N.A. (2002) Evaluation of the NCEPNCAR Reanalysis in the northeast Pacific and the Bering Sea. J. Geophys. Res. 107:3158, 10.1029/2001JC001157.

Mantua, N.J., Hare, S.R., Zhang, Y., Wallace, J.M. and Francis, R.C. (1997) A Pacific interdecadal climate oscillation with impacts on salmon production. Bull. Am. Meteorol. Soc. 78:1069-1079.

Napp, J.M. and Hunt, G.L., (2001) Anomalous conditions in the southeastern Bering Sea, 1997: linkages among climate, weather, ocean and biology. Fish. Oceanogr. 10:61-68.

Napp, J.M., Kendall, A.W. Jr and Schumacher, J.D. (1998) Biophysical processes relevant to recruitment dynamics of walleye pollock (Theragra chalcogramma) in the Eastern Bering Sea. In: Bering Sea FOCI Final Report. S.A. Macklin (ed.). NOAA ERL Special Report, (Available from NTIS, Springfield, VA 221, pp. 71-102).

Napp, J.M., Baier, C.T., Coyle, K.O., Brodeur, R.D., Shiga, N. and Mier, K. (2002) Interannual and decadal variability in zooplankton communities of the southeast Bering Sea Shelf. Deep-Sea Res. II Top. Stud. Oceanogr. 49:5991-6008.

Nof, D. and Im, S.H. (1985) Suction through broad oceanic gaps. J. Phys. Oceanogr. 15:1721-1732.

Olson, M.B. and Strom, S.L. (2002) Phytoplankton growth, microzooplankton herbivory and community structure in the southeast Bering Sea: insight into the formation and temporal persistence of an Emiliania huxleyi bloom. Deep-Sea Res. II Top. Stud. Oceanogr. 49:5969-5990.

Overland, J.E., Adams, J.M. and Bond, N.A. (1999) Decadal variability of the Aleutian Low and its relation to highlatitude circulation. J. Clim. 12:1542-1548.

Overland, J.E., Bond, N.A. and Adams, J.M. (2001) North Pacific atmospheric and SST anomalies in 1997: links to ENSO? Fish. Oceanogr. 10:81-98.

Reed, R.K. and Stabeno, P.J. (2002) Surface heat fluxes and subsurface heat content at a site over the southeastern Bering Sea shelf, May-June 1996. Deep-Sea Res. II Top. Stud. Oceanogr. 49:5911-5917.

Rosenkranz, G.E., Tyler, A.V. and Kruse, G.H. (2001) Effects of water temperature and wind on year-class success of Tanner crabs in Bristol Bay, Alaska. Fish. Oceanogr. 10:1-12.

Sambrotto, R.N., Niebauer, H.J., Goering, J.J. and Iverson, R.L. (1986) Relationships among vertical mixing, nitrate uptake and phytoplankton growth during the spring bloom in the southeast Bering Sea middle shelf. Cont. Shelf Res. 5:161-198.

Schumacher, J.D., Pearson, C.A. and Overland, J.E. (1982) On exchange of water between the Gulf of Alaska and the Bering Sea through Unimak Pass. J. Geophys. Res. 87:57855795.

Stabeno, P.J., Bond, N.A., Kachel, N.B., Salo, S.A. and Schumacher, J.D. (2001) On the temporal variability of the physical environment over the southeastern Bering Sea. Fish. Oceanogr. 10:69-80. 
Stabeno, P.J., Reed, R.K. and Napp, J.M. (2002) Transport through Unimak Pass, Alaska. Deep-Sea Res. II Top. Stud. Oceanogr. 49:5919-5930.

Stabeno, P.J., Bond, N.A., Hermann, A.J., Rachel, N.B., Mordy, C.W. and Overland, J.E. (2004) Meteorology and oceanography of the Northern Gulf of Alaska. Cont. Shelf Res.. 24:859-897.

Stockwell, D.A, Whitledge, T.E., Zeeman, S.I. et al. (2001) Anomalous conditions in the south-eastern Bering Sea, 1997: nutrients, phytoplankton and zooplankton. Fish. Oceanogr. 10:99-116.

Thompson, D.W.J. and Wallace, J.M. (1998) The Arctic Oscillation signature in the wintertime geopotential height and temperature fields. Geophys. Res. Lett. 25:1297-1300.

Vance, T.C., et al. (1998) Aquamarine waters recorded for first time in eastern Bering Sea. EOS Trans. Am. Geophys. Union 79:121-126.
Wallace, J.M. and Gutzler, D.G. (1981) Teleconnections in the geopotential height field during the northern hemisphere winter. Mon. Weather Rev. 109:784-812.

Wespestad, V.G., Fritz, L.W., Ingraham, W.J. and Megrey, B.A. (2000) On relationships between cannibalism, climate variability, physical transport and recruitment success of Bering Sea walleye pollock (Theragra chalcogramma). ICES J. Mar. Sci. 57:272-278.

Whitledge, T.E., Reeburgh, W.S. and Walsh, J.J. (1986) Seasonal inorganic nitrogen distribution and dynamics in the southeastern Bering Sea. Cont. Shelf Res. 5:109-132.

Wyllie-Echeverria, T. and Wooster, W.S. (1998) Year to year variation in Bering Sea ice cover and some consequences for fish distribution. Fish. Oceanogr. 7:159-170.

Yang, S.-K., Hou, Y.-T., Miller, A.J. and Campana, K.A. (1999) Evaluation of the earth radiation budget in NCEP-NCAR reanalysis with ERBE. J. Clim. 12:477-493. 